Original Research

\title{
Evaluasi Kualitatif Penggunaan Antibiotik pada Pasien Pneumonia RS "X" di Malang
}

\author{
Wirda Anggraini ${ }^{1 *}$, Ahmad Subuki Lubis ${ }^{1}$, Siti Maimunah ${ }^{1}$, Abdul Hakim $^{1}$ \\ ${ }^{1}$ Jurusan Farmasi, Fakultas Kedokteran dan IImu Kesehatan, UIN Maulana Malik Ibrahim, Malang-Indonesia \\ * corresponding author: wirdaanggraini93@gmail.com
}

\begin{abstract}
Pneumonia was an inflammation that occurs in the lungs accompanied by exudation and consolidation of microorganisms. In Indonesia, the prevalence of pneumonia continues to increase. Treatment of pneumonia uses antibiotic therapy. The use of antibiotics needs to be controlled by evaluating the quality of antibiotic use to prevent negative effects that can occur on patients, such as antibiotic resistance. The purpose of this study was to determine the rationality of antibiotic use in pneumonia patients. This study did with an observational method with a cross-sectional design. The study was conducted in August-September 2019. Qualitative evaluations did with Gyssen method. The results of 35 medical record samples that fulfill the criteria showed that $13,24 \%$ of cases category $0 ; 10,29 \%$ of cases category I; $0 \%$ of cases category II C; $20,59 \%$ of cases in category II B; $2,94 \%$ of cases category II A; $0 \%$ of cases category III B; $0 \%$ of cases category III A; $0 \%$ of cases category IV D; $11,76 \%$ of cases category IV C; $2,94 \%$ of cases category IV B; $38,24 \%$ of cases category IV A; $0 \%$ of cases category V; $0 \%$ of cases category VI. Rational cases (category 0 ) were $13,24 \%$ and irrational cases (categories I-IV) were $86,76 \%$.
\end{abstract}

Keywords: antibiotic, evaluation, gyssen, pneumonia

\begin{abstract}
Abstrak-Pneumonia adalah peradangan yang terjadi pada paru-paru yang disertai dengan adanya eksudasi dan konsolidasi mikroorganisme. Di Indonesia, prevalensi kejadian pneumonia terus mengalami peningkatan. Pengobatan pneumonia menggunakan terapi antibiotik dan terapi suportif. Penggunaan antibiotik perlu dikendalikan dengan evaluasi kualitas penggunaan antibiotik untuk mencegah dampak negatif yang bisa terjadi pada pasien, salah satunya resistensi antibiotik. Tujuan penelitian ini adalah untuk mengetahui rasionalitas penggunaan antibiotik pada pasien pneumonia. Penelitian ini dilakukan dengan metode observasional dengan desain cross-sectional. Penelitian dilaksanakan pada bulan Agustus-September 2019. Evaluasi kualitatif dilakukan dengan menggunakan metode gyssen. Hasil evaluasi 35 sampel rekam medis yang memenuhi kriteria menunjukkan bahwa 13,24\% kasus kategori 0; 10,29\% kasus kategori I; 0\% kasus kategori II C; 20,59\% kasus kategori II B; 2,94\% kasus kategori II A; 0\% kasus kategori III B; 0\% kategori III A; $0 \%$ kasus kategori IV D; $11,76 \%$ kasus yang masuk kategori IV C; 2,94\% kasus kategori IV B; 38,24\% kategori IV A; $0 \%$ kategori V; $0 \%$ kasus kategori VI. Kasus yang rasional (kategori 0) sebanyak 13,24\% dan kasus yang tidak rasional (kategori I-IV) sebanyak $86,76 \%$.
\end{abstract}

Kata kunci: antibiotik, evaluasi, gyssen, pneumonia

\section{PENDAHULUAN}

Pneumonia adalah peradangan yang terjadi pada paru-paru yang disertai dengan adanya eksudasi dan konsolidasi, biasanya disebabkan oleh mikroorganisme seperti bakteri, jamur, virus, dan parasit (Dorland, 2014). Mikrooganisme penginfeksi terbanyak yang menyebabkan pneumonia adalah S. Pneumoniae. Mikroorganisme lain yang menyebabkan pneumonia seperti $M$. Pneumonia, H. Influenza, Legionella species, dan C. Pneumoniae (Prina, et al., 2015). Prognosis penyakit pneumonia sangat tergantung pada mikrooganisme patogen, volume aspirasi, frekuensi aspirasi, dan virulensi mikroorganisme terhadap sistem imun penderita pneumonia (Lanks, et al., 2019).

Kasus kematian yang diakibatkan oleh pneumonia di dunia diperkirakan mencapai 935.000 jiwa pertahun dan lebih dari 2.500 jiwa perhari meninggal dunia (WHO, 2014). Angka kejadian pneumonia di Eropa sebesar 68-700 kasus per 100.000 penduduk dengan 16-3581 kasus pasien mendapatkan perawatan di rumah sakit (Torres et al., 2013). Kasus Pneumonia komunitas di Amerika serikat terdapat lebih dari 1.500 .000 kasus setiap tahunnya dan 100.000 kematian karena pneumonia terjadi di rumah sakit (Ramirez et al., 2017). Angka kematian akibat pneumonia di Asia 
mencapai 1.000.000 kematian per tahun. Kasus kematian pada orang tua sangat banyak ditemukan, namun sejumlah 160.000 kasus kematian terjadi pada usia produktif (Peto et al., 2014). Sementara itu, hasil survei data yang dilakukan oleh lembaga di Indonesia pada tahun 2014 melaporkan bahwa angka kematian yang terjadi akibat penyakit pneumonia mencapai 944.000 jiwa dari 5,9 juta jiwa (Ditjen P2PL, 2015). Prevalensi pneumonia di Indonesia sendiri cenderung meningkat dari 2,1\% pada tahun 2007 menjadi 4,0 \% pada tahun 2013 dan 4,5\% pada tahun 2018 (Kemenkes RI, 2018).

Pneumonia merupakan kasus infeksi yang dapat diobati dengan menggunakan terapi antibiotik dan terapi suportif. Antibiotik dapat diberikan kepada pasien pneumonia sebagai terapi empiris apabila belum dilakukan proses kultur dan sebagai terapi definitif apabila sudah diketahui bakteri penyebab terjadinya pneumonia (PDPI, 2014). Penggunaan antibiotik yang relatif tinggi dapat menimbulkan resistensi antibiotik. Peningkatan resistensi antibiotik yang sering digunakan dalam terapi empiris oleh klinisi dapat menyebabkan berkurangnya keefektivan terapi terhadap pneumonia. Penelitian yang dilakukan di RSUP Dr. M. Djamil Padang menemukan bahwa pola resistensi bakteri penyebab pneumonia terhadap antibiotik menunjukkan Ampisilin dan Eritromisin menjadi antibiotik dengan resistensi tertinggi diikuti Kotrimoksazol, Sefiksim, Tetrasiklin, Kloramfenikol, Amoksisilin-klavulanat, dan Ampisilin-Sulbaktam (Kurniawan dkk., 2015). Penelitian kualitas pengggunaan antibiotik di beberapa rumah sakit menemukan sekitar 30$80 \%$ penggunaan antibiotik yang tidak tepat indikasi (Kemenkes $\mathrm{RI}, 2013 \mathrm{a}$ ). Penggunaan antibiotik perlu dikendalikan untuk mencegah dampak negatif terhadap flora normal pasien, toksisitas antibiotik yang meningkat, biaya perawatan yang membengkak karena lama perawatan yang bertambah, dan terbentuknya kolonisasi patogen yang resisten terhadap antibiotik (Dipiro et al., 2015).

Evaluasi penggunaan antibiotik menjadi salah satu indikator mutu program pengendalian resistensi antibiotik di rumah sakit. Evaluasi penggunaan antibiotik dapat dilakukan dengan menggunakan metode kualitatif dan kuantitatif. Evaluasi kualitatif dilakukan untuk menilai kualitas penggunaan antibiotik. Metode evaluasi yang digunakan yaitu metode Gyssens. Keuntungan menggunakan metode Gyssens dalam evaluasi penggunaan antibiotik, yaitu metode Gyssens dapat menilai penggunaan antibiotik yang rasional (kategori 0) dan penggunaan antibiotik yang tidak rasional (kategori I-IV). Metode Gyssens berbentuk diagram alir yang dapat mengevaluasi seluruh aspek peresepan antibiotik, seperti: penilaian alternatif antibiotik yang lebih efektif, antibiotik yang lebih tidak toksis, antibiotik yang lebih murah, spektrum antibiotik yang lebih sempit, lama pengobatan, dosis antibiotik, interval pemberian antibiotik, rute pemberian antibiotik dan waktu pemberian antibiotik (Gyssens et al., 2005; Permenkes RI, 2015).

Penelitian sebelumnya yang dilakukan oleh Dewi dan Mutmainah di Balai Kesehatan " $X$ " Surakarta tentang evaluasi kualitas penggunaan antibiotik pada pasien pneumonia dengan metode Gyssens menemukan 4 kasus penggunaan antibiotik rasional $(11,11 \%)$ dan ada 32 kasus penggunaan antibiotik tidak rasional (88,89\%) (Dewi dan Mutmainah, 2014). Sedangkan penelitian yang dilakukan oleh Rusmini di RSUD H. Abdul Moeloek menemukan bahwa sebanyak 44,7\% penggunaan antibiotik yang rasional dan 55,3\% penggunaan antibotik yang tidak rasional, sehingga ketidakrasionalan penggunaan antibiotik pada pasien pneumonia rawat inap masih tergolong tinggi (Rusmini, 2015). Penelitian ini bertujuan untuk mengetahui kualitas penggunaan antibiotik pada pasien pneumonia rawat inap di RSUD Kanjuruhan Kabupaten Malang.

\section{METODE}

Penelitian ini menggunakan metode observasional secara retrospektif dengan desain cross sectional. Penelitian dilaksanakan pada bulan Agustus-September 2019 di ruang rekam medis RSUD Kanjuruhan Kabupaten Malang. Variabel yang digunakan pada penelitian ini adalah 
rasionalitas penggunaan antibiotik pada pasien pneumonia rawat inap. Data yang digunakan adalah data sekunder berupa data rekam medis pasien. Populasi dalam penelitian ini adalah seluruh rekam medis pasien pneumonia yang dirawat inap, yaitu sebanyak 53 rekam medis. Pengambilan sampel dilakukan dengan menggunakan teknik purposive sampling. Sampel yang digunakan dalam penelitian adalah seluruh populasi data periode Januari 2017-Juni 2019 yang memenuhi kriteria inklusi dan eksklusi. Kriteria inklusi penelitian ini adalah rekam medis pasien yang didiagnosa pneumonia, rekam medis pasien yang mendapatkan terapi antibiotik, rekam medis yang lengkap, dan rekam medis pasien dewasa (18-65 tahun). Kriteria eksklusi penelitian ini adalah rekam medis pasien yang meninggal, rekam medis pasien yang di rujuk ke rumah sakit lain. Perhitungan minimal sampel dilakukan dengan menggunakan metode Slovin dengan margin of error $10 \%$, sehingga didapatkan jumlah sampel minimal sebanyak 35 rekam medis.

Instrumen yang digunakan pada penelitian ini yaitu Lembar Pengambilan Data (LPD), alat tulis, Laptop, dan guidelines penggunaan antibiotik pada pasien pneumonia. Guidelines yang digunakan yaitu Drug Information Handbook Ed.24 tahun 2015, Penatalaksanaan Pneumonia Komuniti PDPI tahun 2014, Penatalaksanaan Pneumonia Nosokomial PDPI tahun 2005, MIMS Edisi 18 Tahun 2018, Infectious Disease Society of America/American Thoracic Society (IDSA/ATS) Pneumonia Komuniti (CAP) tahun 2019, IDSA/ATS Pneumonia Nosokomial tahun 2016, dan Jhon Hopkins Antibiotic Guideline tahun 2016. Data diolah dengan menggunakan aplikasi Microsoft Excel 2016. Analisis data yang dilakukan berupa analisis deskriptif yang hasilnya disajikan dalam bentuk tabel dan uraian deskriptif. Evaluasi Gyssens pada penggunaan antibiotik dimulai dari kategori VI, kemudian dilanjutkan ke kategori V, IV, III, II, I. Hasil evaluasi antibiotik yang masuk kategori 0 adalah antibiotik yang tidak termasuk kategori VI-I. Antibiotik yang tidak lolos kriteria Gyssens kategori VI, V, dan I tidak dapat dilanjutkan evaluasi ke kategori selanjutnya (IV-0). Namun, antibiotik yang tidak lolos kriteria Gyssens kategori IV-II evaluasinya bisa dilanjutkan ke kategori selanjutnya. Kriteria Gyssens kategori VI-0 dapat dilihat pada Tabel 3. Data yang diperoleh pada penelitian ini yaitu demografi pasien, profil antibiotik, dan hasil evaluasi metode Gyssens. Perhitungan persentase penggunaan antibiotik dilakukan dengan membandingkan anara jumlah penggunaan masing-masing antibiotik dan total jumlah peresepan antibiotik. Perhitungan persentase Gyssens dilakukan dengan membandingkan antara jumlah peresepan antibiotik dan jumlah total kasus Gyssens kategori 0-VI.

\section{HASIL}

\section{Demografi Pasien Pneumonia}

Hasil penelitian ini di peroleh data rekam medis pasien pneumonia. Berdasarkan kriteria inklusi didapatkan 35 sampel rekam medis yang memenuhi kriteria inklusi. Data demografi pasien terdiri atas usia pasien dan jenis kelamin. Data usia pasien dikelompokkan berdasarkan kategori usia yang telah ditetapkan oleh Kementrian Kesehatan RI tahun 2009 (Kemenkes RI, 2009). Demografi pasien dapat dilihat pada Tabel 1. 
Tabel 1

Profil Demografi Pasien Pneumonia

\begin{tabular}{|c|c|c|c|}
\hline \multicolumn{2}{|c|}{ Demografi Pasien } & Jumlah $(\mathrm{N}=35)^{*}$ & Presentase $(\mathrm{N}=100 \%)$ \\
\hline \multirow[t]{5}{*}{ Usia Pasien } & 18-25 tahun & 7 & 20 \\
\hline & 26-35 tahun & 3 & 8,6 \\
\hline & $36-45$ tahun & 5 & 14,3 \\
\hline & 46-55 tahun & 9 & 25,7 \\
\hline & 56-65 tahun & 11 & 31,4 \\
\hline \multirow{2}{*}{$\begin{array}{l}\text { Jenis } \\
\text { Kelamin }\end{array}$} & Laki-laki & 25 & 71,4 \\
\hline & Perempuan & 10 & 28,6 \\
\hline
\end{tabular}

Keterangan: *jumlah sampel rekam medis

\section{Profil Penggunaan Antibiotik Pasien Pneumonia}

Profil penggunaan antibiotik pada pasien pneumonia dikelompokkan berdasarkan jenis terapi yang diberikan, golongan antibiotik, dan jenis antibiotik nya. Jumlah penggunaan antibiotik sebanyak 42 antibiotik pada 35 rekam medis pasien yang diteliti. Hal ini karena adanya penggantian antibiotik sebanyak 7 antibiotik. Profil penggunaan antibiotik pasien pneumonia dapat dilihat pada Tabel 2.

Tabel 2

Profil Penggunaan Antibiotik Pada Pasien Pneumonia

\begin{tabular}{|c|c|c|c|c|}
\hline Jenis Terapi & Golongan & Jenis Antibiotik & Jumlah & Persentase \\
\hline \multirow[t]{6}{*}{ Antibiotik Tunggal } & Fluorokuinolon & Levofloksasin & 10 & $23,81 \%$ \\
\hline & Penisilin- Betalaktamase & $\begin{array}{l}\text { Ampisilin- } \\
\text { Sulbaktam }\end{array}$ & 9 & $21,43 \%$ \\
\hline & Sefalosporin Generasi 3 & Sefoperazon & 9 & $21,43 \%$ \\
\hline & Sefalosporin Generasi 2 & Sefuroksim & 5 & $11,91 \%$ \\
\hline & Sefalosporin Generasi 3 & Seftriakson & 3 & $7,14 \%$ \\
\hline & Sefalosporin Generasi 3 & Sefotaksim & 2 & $4,76 \%$ \\
\hline \multirow[t]{3}{*}{ Antibiotik Kombinasi } & $\begin{array}{l}\text { Fluorokuinolon + } \\
\text { Sefalosporin Generasi } 3\end{array}$ & $\begin{array}{l}\text { Levofloksasin + } \\
\text { Sefaporazon }\end{array}$ & 2 & $4,76 \%$ \\
\hline & $\begin{array}{l}\text { Fluorokuinolon + } \\
\text { Sefalosporin Generasi } 3\end{array}$ & $\begin{array}{l}\text { Levofloksasin + } \\
\text { Seftriakson }\end{array}$ & 1 & $2,38 \%$ \\
\hline & $\begin{array}{l}\text { Fluorokuinolon }+ \\
\text { Sefalosporin Generasi } 2\end{array}$ & $\begin{array}{l}\text { Levofloksasin } \\
\text { +Sefuroksim }\end{array}$ & 1 & $2,38 \%$ \\
\hline
\end{tabular}

Keterangan: Terdapat 5 pasien menerima penggantian antibiotik (total 7 antibiotik pengganti):

1 pasien pergantian antibiotik kombinasi Levofloksasin Sefoperazone ke Levofloksasin lalu diganti ke AmpisilinSulbaktam

1 pasien pergantian antibiotik Levofloksasin, lalu diganti ke kombinasi Levofloksasin Seftriakson

1 pasien pergantian antibiotik Sefuroksim ke Sefoperazon

1 pasien pergantian antibiotik Sefoperazone ke Sefotaksim

1 pasien pergantian antibiotik Seftriakson ke Sefotaksim 


\section{Evaluasi Kualitatif Penggunaan Antibiotik}

Evaluasi kualitatif penggunaan antibiotik pada pasien pneumonia dilakukan dengan menggunakan metode Gyssens untuk menilai rasionalitas penggunaan antibiotik pada pasien pneumonia. Hasil evaluasi kualitatif dengan metode Gyssens dapat dilihat pada Tabel 3.

Berdasarkan data tabel 3, didapatkan 42 kasus peresepan antibiotik dari 35 rekam medis pasien pneumonia rawat inap. Hasil penggunaan antibiotik rasional didapatkan dengan melakukan pengelompokkan antibiotik yang lolos dan tidak lolos kategori Gyssens berdasarkan guideline yang digunakan. Antibiotik yang tidak lolos kategori gyssen dapat ditempatkan dalam lebih dari satu kategori Gyssens dengan alasan yang berbeda pada saat yang sama. Sehingga, antibiotik yang tidak lolos kategori Gyssens IV-II dapat ditempatkan pada lebih dari 1 kategori Gyssens (Gyssens, 2005). Hasil total kasus penggunaan antibiotik yang masuk kategori gyssen $0-\mathrm{VI}$ adalah 68 . Evaluasi kualitatif yang dilakukan pada penelitian ini hanya penggunaan antibiotik untuk terapi empiris, karena belum dilakukan pemeriksaan kultur bakteri pasien.

\section{Tabel 3}

Hasil Evaluasi Kualitatif Penggunaan Antibiotik Pada Pasien Pneumonia

\begin{tabular}{|c|c|c|c|c|}
\hline $\begin{array}{l}\text { Kategori } \\
\text { Gyssens }\end{array}$ & Kriteria Gyssens & $\begin{array}{l}\text { No. Peresepan } \\
\text { Antibiotik }(n=42) *\end{array}$ & Jumlah & Persentase \\
\hline $\mathrm{VI}$ & $\begin{array}{l}\text { Data rekam medik tidak lengkap dan } \\
\text { tidak dapat dievaluasi }\end{array}$ & - & 0 & $0 \%$ \\
\hline V & $\begin{array}{l}\text { Tidak ada indikasi penggunaan } \\
\text { antibiotik }\end{array}$ & - & 0 & $0 \%$ \\
\hline IV A & Ada antibiotik lain yang lebih efektif & $\begin{array}{l}1,3,4,8,9,11,12 \\
13,14,17,18,20 \\
22,23,24,25,26 \\
28,29,32,34,36 \\
37,38,39,40\end{array}$ & 26 & $38,24 \%$ \\
\hline IV B & $\begin{array}{l}\text { Ada antibiotik lain yang lebih tidak } \\
\text { toksik/aman }\end{array}$ & 5,41 & 2 & $2,94 \%$ \\
\hline IV C & Ada antibiotik lain yang lebih murah & $\begin{array}{l}20,21,22,24,25 \\
28,37,40\end{array}$ & 8 & $11,76 \%$ \\
\hline IV D & $\begin{array}{l}\text { Ada antibiotik lain yang spektrumnya } \\
\text { lebih sempit }\end{array}$ & - & 0 & $0 \%$ \\
\hline III A & Penggunaan antibiotik terlalu lama & - & 0 & $0 \%$ \\
\hline III B & Penggunaan antibiotik terlalu singkat & - & 0 & $0 \%$ \\
\hline II A & $\begin{array}{l}\text { Penggunaan antibiotik tidak tepat } \\
\text { dosis }\end{array}$ & 13,21 & 2 & $2,94 \%$ \\
\hline II B & $\begin{array}{l}\text { Penggunaan antibiotik tidak tepat } \\
\text { interval pemberian }\end{array}$ & $\begin{array}{l}1,3,4,8,9,11,13 \\
14,16,17,18,26 \\
34,39\end{array}$ & 14 & $20,59 \%$ \\
\hline II C & $\begin{array}{l}\text { Penggunaan antibiotik tidak tepat } \\
\text { rute }\end{array}$ & - & 0 & $0 \%$ \\
\hline I & $\begin{array}{l}\text { Penggunaan antibiotik tidak tepat } \\
\text { waktu }\end{array}$ & $\begin{array}{l}1,7,18,19,26,30 \\
37\end{array}$ & 7 & $10,29 \%$ \\
\hline \multirow[t]{2}{*}{0} & Penggunaan antibiotik rasional & $\begin{array}{l}2,6,10,15,27,31 \\
33,35,42\end{array}$ & 9 & $13,24 \%$ \\
\hline & & Total** & 68 & $100 \%$ \\
\hline
\end{tabular}


Keterangan: $\quad{ }^{*} n=42$ adalah jumlah antibiotik yang diteliti dengan menggunakan metode Gyssens

** jumlah kasus hasil evaluasi antibiotik secara Gyssens

\section{BAHASAN}

\section{Demografi Pasien Pneumonia}

Penyakit pneumonia rawat inap yang tertinggi terjadi pada pasien dengan rentang usia 5665 tahun yaitu sebanyak 11 pasien (31,4\%) (tabel 1). Hasil penelitian ini sesuai dengan penelitian di RSUD Dr. Moewardi tahun 2017 bahwa pasien pneumonia terbanyak pada kelompok usia 56-65 tahun sebanyak 40 pasien $(25,7 \%)$ (Muhammad, 2018). Hasil penelitian ini juga sesuai dengan penelitian sebelumnya di salah satu Rumah Sakit Klaten tahun 2015 yang menemukan bahwa penumonia paling banyak diderita oleh pasien berusia $>60$ tahun yaitu sebanyak 23 pasien (50\%) (Safitri, 2017). Namun, hasil penelitian ini sedikit berbeda dengan penelitian yang dilakukan di RSUD Cengkareng tahun 2013-2014 yang menemukan pasien pneumonia terbanyak pada kelompok usia 45-59 tahun sebanyak 55 pasien (56,7\%) (Jalil, 2015). Kategori kelompok usia terbanyak penelitian ini berbeda dengan penelitian lain kemungkinan disebabkan oleh perbedaan kategori usia dan kriteria inklusi yang digunakan.

Data pada Tabel 1 menunjukkan bahwa usia yang semakin tua memiliki dampak yang cukup tinggi terhadap kejadian pneumonia. Risiko infeksi saluran pernapasan bawah, salah satunya pneumonia, semakin meningkat seiring dengan bertambahnya usia. Hal ini berkaitan dengan penurunan fungsional dan sturuktural sistem pernapasan. Perubahan anatomi dan fungsional sistem pernapasan disebabkan oleh perubahan struktur dan anatomi pada paru, seperti: pengecilan diameter bronkiolus, perubahan cross-linking matriks (elastin dan kolagen), gangguan dan hilangnya serabut elastin, pembesaran bronkiolus respiratorius, dan pengurangan jumlah kapiler per alveolus (Hasan \& Rena, 2017).

Hasil penelitian menunjukkan bahwa pasien pneumonia berjenis kelamin laki-laki $(71,4 \%)$ lebih banyak dibandingkan perempuan (28,6\%). Hasil penelitian ini sesuai dengan penelitian yang dilakukan di RSUD Dr. Moewardi tahun 2017 yang menemukan bahwa 51,9\% kejadian pneumonia dialami oleh laki-laki dewasa (Muhammad, 2018). Faktor yang dapat mempengaruhi banyaknya jumlah pasien laki-laki yang menderita pneumonia di RSUD Kanjuruhan adalah tingginya aktivitas atau pekerjaan yang dilakukan oleh laki-laki dibandingkan perempuan. Laki-laki lebih mudah terserang pneumonia karena lebih sering memiliki kegiatan diluar rumah untuk bekerja. Hal ini menyebabkan laki-laki lebih mudah terkontaminasi udara kotor yang tercemar, yaitu polusi udara yang mengandung zat kimia pemicu infeksi pada paru-paru (Marsono, 2015).

Faktor lain yang dapat menyebabkan pneumonia adalah kebiasaan merokok. Hasil penelitian sebelumnya menyatakan bahwa konsumsi rokok dan zat-zat patogen lainnya memicu penurunan daya tahan tubuh pada laki-laki yang semakin meningkatkan timbulnya infeksi khususnya ISPA (Andayani, 2014). Laki-laki dewasa sehat yang terpapar asap rokok terus-menerus dapat menyebabkan peningkatan risiko terjadinya infeksi pada paru-paru. Manifestasi klinis yang dapat terjadi seperti bronkitis, pneumonia, dan penyakit paru-paru lainnya (Elfidasari dkk., 2013). Hasil Riset Kesehatan Dasar (Riskesdas) tahun 2013 mencatat bahwa perilaku merokok pada penduduk usia 15 tahun keatas terus mengalami peningkatan dari 34,3\% pada tahun 2007 menjadi 36,3\% pada tahun 2013. Hasil Riskesdas juga menunjukkan bahwa sebanyak $64,9 \%$ penduduk berjenis kelamin laki-laki adalah perokok (Kemenkes RI, 2013b).

\section{Profil Penggunaan Antibiotik Pasien Pneumonia}

Terapi antibiotik terbanyak yang diberikan pada pasien pneumonia rawat inap periode Januari 2017-Juni 2019 di RSUD Kanjuruhan Kabupaten Malang adalah antibiotik Levofloksasin sebanyak 10 antibiotik (23,81\%). Penelitian sebelumnya di salah satu Rumah Sakit Kota Bantul juga 
menemukan bahwa antibiotik yang paling banyak digunakan oleh pasien pneuomonia rawat inap adalah Levofloksasin (42,7\%) (Aulia dan Cahyaningsih, 2017). Persatuan Dokter Paru Indonesia (PDPI) juga merekomendasikan antlbiotik levofloksasin digunakan sebagai lini pertama terapi empiris pneumonia komuniti (Community-Acquired Pneumonia) dan lini ketiga terapi empiris pneumonia nosokomial (Hospital-Acquired Pneumoia) (PDPI, 2014). Hal ini juga sesuai dengan guideline Infectious Disease Society of America (IDSA) (2019), Drug Information Handbook edisi 24 (2015), guideline pneumonia nosokomial dari Persatuan Dokter Paru Indonesia (PDPI) (2005), Infectious Disease Society of America (IDSA) (2016), dan Drug Information Handbook edisi 24 (2015).

Levofloksasin adalah antibiotik golongan kuinolon (Fluorokuinolon) yang mempunyai aktivitas menghambat sintesis DNA bakteri. Levofloksasin memiliki spektrum luas, sehingga bisa digunakan untuk menghambat bakteri gram positif dan bakteri gram negatif. Levofloksasin dapat menghambat bakteri Stereptococcus pneumoniae dan Pseudomonas aeruginosa (Fair dan Tor, 2014).

Antibiotik Ampisilin-Sulbaktam dan Sefoperazon menempati penggunaan antibiotik kedua terbanyak (21,43\%). Penelitian yang dilakukan di RS UNS Sukoharjo menemukan bahwa Seftriaxone $(18,2 \%)$ digunakan sebagai terapi antibiotik kedua terbanyak pada pasien pneumonia rawat inap tahun 2018 (Farida, dkk. 2020). Antibiotik Ampisilin-Sulbaktam, Sefoperazon, dan Seftriakson berdasarkan mekanisme kerjanya termasuk antibiotik golongan Betalaktam. Guideline yang digunakan menyebutkan bahwa antibiotik golongan Betalaktam+Makrolida adalah lini pertama pengobatan pneumonia komunitas dan antibiotik tunggal golongan Betalaktam adalah lini pertama pengobatan pnuemonia nosokomial (IDSA, 2019; IDSA, 2016; PDPI, 2014; PDPI, 2005). Ampisilin-Sulbaktam adalah antibiotik golongan penisilin yang ditambah dengan inhibitor Betalaktamase. Sefoperazon dan Seftriakson adalah antibiotik golongan Sefalosporin. Ketiga antibiotik tersebut mempunyai aktivitas menghambat enzim peptidase pada dinding sel bakteri (peptidoglikan) yang mengakibatkan terhambatnya biosintesis dinding sel, sehingga terjadi lisis bakteri (Fair \& Tor, 2014).

Antibiotik kombinasi terbanyak yang digunakan yaitu kombinasi Levofloksasin+Sefoperazon sebesar 2 antibiotik (4,88\%). Penelitian lain tentang penggunaan antibiotik pasien pneumonia rawat inap di RS " $X$ " Jakarta juga menemukan bahwa antibiotik kombinasi yang paling banyak digunakan adalah kombinasi Betalaktam+Fluorokuinolon (11,46\%) (Elvina dkk., 2017). Pasien CAP yang mengalami pneumonia berat dapat diberikan terapi empiris kombinasi antibiotik Betalaktam+Fluorokuinolon (PDPI, 2014; IDSA, 2019).

\section{Evaluasi Kualitatif Penggunaan Antibiotik}

Berdasarkan hasil evaluasi dari 42 kasus penggunaan antibiotik pada pasien pneumonia di RSUD Kanjuruhan Kabupaten Malang terlihat hanya beberapa kategori Gyssens yang terpenuhi. Kategori Gyssens tertinggi yaitu kategori IV A $(38,24 \%)$ yang diikuti kategori II B $(20,59 \%)$ dan kategori 0 (13,24\%). Kategori gyssen terendah yaitu kategori VI $(0 \%)$, kategori V $(0 \%)$, kategori IV D (0\%), kategori III B (0\%), dan kategori II C (0\%).

\section{Kategori VI (data tidak lengkap)}

Data tidak lengkap adalah data rekam medis tanpa diagnosa pneumonia atau ada halaman rekam medis yang hilang, sehingga tidak dapat dievaluasi. Kelengkapan data rekam medis di 
evaluasi untuk dapat menilai lebih lanjut mengenai penggunaan antibiotik yang rasional. Kelengkapan data dari semua rekam medis pasien pneumonia harus memenuhi semua kategori Gyssens (ada indikasi pemberiaan antibiotik, data dosis antibiotik, lama pemberian antibiotik, interval pemberian antibiotik, waktu pemberian antibiotik) disamping data pasien lainnya (Kemenkes RI, 2011). Hasil penelitian dari 42 kasus penggunaan antibiotik menemukan bahwa semua kasus tidak termasuk kategori VI, sehingga evaluasi dapat dilanjutkan ke kriteria Gyssens kategori V.

\section{Kategori V (tidak ada indikasi penggunaan antibiotik)}

Tidak ada indikasi penggunaan antibiotik yaitu pemberian antibiotik terjadi pada pasien yang kondisi klinis dan kondisi selama rawat inap tidak memerlukan penggunaan antibiotik. Indikasi penggunaan antibiotik dilihat dari diagnosis dokter, hasil laboratorium pasien, kondisi pasien, serta tanda vital pasien pada rekam medis. Hasil evaluasi ditemukan bahwa semua kasus penggunaan antibiotik tidak termasuk kategori $\vee$ sehingga, evaluasi dapat dilanjutkan ke kriteria Gyssens kategori IVA.

\section{Kategori IV A (ada antibiotik lain yang lebih efektif)}

Ada antibiotik lain yang lebih efektif artinya antibiotik lain lebih direkomendasikan penggunaannya berdasarkan guideline pneumonia komunitas PDPI tahun 2014, pneumonia nosokomial PDPI tahun 2005, IDSA CAP tahun 2019, IDSA HAP tahun 2016, dan APhA tahun 2015. Evaluasi dilakukan dengan membandingkan antara terapi antibotik yang diterima pasien dan terapi antibiotik yang direkomendasikan oleh guideline. Hasil evaluasi menemukan bahwa 22 kasus penggunaan antibiotik tidak lolos penilaian Gyssens dan masuk kategori IV A yaitu antibiotik Ampisilin-Sulbaktam (kasus No. 1, 3, 4, 8, 9, 11, 13, 14, dan 17), antibiotik Sefoperazon (kasus No. $12,23,26,29,32,36$, dan 37), antibiotik Sefuroksim (kasus No. 20, 22, 24, 25, dan 28), antibiotik Seftriakson (kasus No. 18, 34, dan 39), dan antibiotik Sefotaksim (kasus No. 38 dan 40). Kasus penggunaan Ampisilin-Sulbaktam dan Sefalosporin tunggal (Sefoperazon, Sefuroksim, dan Sefotaksim) pada pneumonia komunitas dinilai kurang tepat sebagai lini pertama terapi karena masih ada antibiotik lain yang merupakan lini pertama terapi yaitu kombinasi AmpisilinSulbaktam+Makrolida (PDPI, 2014; IDSA CAP, 2019; ApHA, 2015).

\section{Kategori IV B (ada antibiotik lain yang lebih tidak toksik/aman)}

Ada antibiotik lain yang lebih tidak toksik/aman artinya antibiotik yang diberikan kontraindikasi dengan kondisi klinis pasien. Kondisi klinis yang diperhatikan yaitu data hasil laboratorium SGOT, SGPT, BUN, dan kreatinin pasien. Analisis dilakukan dengan membandingkan kondisi klinis dan kondisi pasien dengan data keamanan antibiotik dalam guideline Drug Information Handbook dari APhA tahun 2015. Hasil evaluasi Gyssens menemukan bahwa ada 2 kasus (kasus No. 5 dan 41) yang tidak lolos penilaian Gyssens dan masuk kategori IV B. Kedua kasus merupakan penggunaan Levofloksasin pada pasien yang memiliki nilai SGOT dan SGPT di atas normal. Kasus No. 5 menyebabkan pasien mengalami hepatitis reaktif. Levofloksasin bersifat hepatotoksik, sehingga perlu dipertimbangkan untuk penggantian antibiotik Levofloksasin dengan antibiotik golongan lain yang lebih aman bagi pasien (APhA, 2015).

\section{Kategori IV C (ada antibiotik lain yang lebih murah)}

Ada antibiotik lain yang lebih murah artinya masih ada antibiotik generik yang lebih murah. Evaluasi untuk antibiotik yang tidak memiliki jenis generik dilakukan dengan membandingkan harga antibiotik bermerek yang bahan aktifnya sama. Evaluasi kategori IV C dilakukan dengan membandingkan antara harga antibiotik di RSUD Kanjuruhan dan harga obat 
pada e-catalog tahun 2018, MIMS edisi 18 tahun 2018, dan ISO edisi 50 tahun 2016. Hasil evaluasi menemukan bahwa 8 kasus penggunaan antibiotik tidak lolos penilaian Gyssens dan masuk dalam kategori IV C, yaitu: antibiotik merek Sharox (Sefuroksim) (kasus No. 20, 22, 24, 25, dan 28), antibiotik merek Taxegram (Sefotaksim) (kasus No. 37 dan 40), dan antibiotik merek Anbacim (Sefuroksim) (kasus No. 21). Harga obat merek Sharox, Taxegram, dan Anbacim lebih mahal dibandingkan dengan harga obat generiknya (e-catalog, 2018; MIMS, 2018, ISO, 2016).

\section{Kategori IV D (ada antibiotik lain yang spektrumnya lebih sempit)}

Ada antibiotik lain yang spektrumnya lebih sempit yaitu penilaian terhadap kesesuaian penggunaan antibiotik dengan hasil kultur pasien. Semua data rekam medis yang diteliti tidak mempunyai data hasil kultur pasien karena penggunaan antibiotik ditujukan untuk terapi empiris. Evaluasi kategori IV D dilakukan dengan menilai penggunaan antibiotik spektrum luas untuk terapi empiris. Hasil evaluasi ditemukan bahwa tidak ada kasus penggunaan antibiotik yang masuk kategori IV D. Antibiotik Levofloksasin, Ampisilin-Sulbaktam, Sefoperazon, Sefuroksim, Seftriakson, dan Sefotaksim yang diberikan pada pasien merupakan antibiotik spektrum luas (board spectrum) yang sudah sesuai dengan guideline.

\section{Kategori III A (penggunaan antibiotik terlalu lama) dan kategori III B (penggunaan antibiotik terlalu singkat)}

Penggunaan antibiotik terlalu lama artinya pasien menggunakan antibiotik melebihi lama pemberian terapi antibiotik yang direkomendasikan. Penggunaan antibiotik terlau singkat artinya pasien menggunakan antibiotik kurang dari lama pemberian yang direkomendasikan. Lama terapi untuk pasien pneumonia mengacu pada guideline yang digunakan. Menurut guideline IDSA (2019), APhA (2015), dan Jhon Hopkins antibiotic guideline (2016), lama pemberian antibiotik untuk terapi pneumonia komunitas yaitu 3-14 hari. Menurut guideline PDPI (2014), lamanya pemberian antibiotik untuk terapi empiris CAP rata-rata 5 hari. Menurut PDPI (2005), lama pemberian antibiotik pada pasien HAP adalah 3-21 hari. Menurut IDSA (2016), rekomendasi lama pemberian antibiotik pada pasien HAP adalah 7 hari, akan tetapi lama pemberian bisa lebih lama atau lebih cepat jika belum terjadi perbaikan klinis pada pasien. Berdasarkan hasil evaluasi, semua kasus penggunaan antibiotik pada pasien pneumonia rawat inap tidak ada yang masuk kategori III A dan kategori III B.

\section{Kategori II A (penggunaan antibiotik tidak tepat dosis)}

Penggunaan antibiotik tidak tepat dosis yaitu evaluasi untuk melihat ketidaksesuaian dosis antibiotik yang digunakan dengan rentang dosis antibiotik dalam guideline. Evaluasi kategori II A dilakukan dengan membandingkan antara dosis antibiotik yang didapat pasien sesuai rekam medis dan dosis antibiotik pada guideline yang digunakan. Berdasarkan hasil evaluasi didapatkan 2 kasus yang tidak lolos kriteria Gyssens dan masuk kategori II A yaitu antibiotik Ampisilin-Sulbaktam (kasus No. 13) dan antibiotik Sefotaksim (kasus No.21). Kasus No. 13 terjadi pada pasien HAP yang diberikan antibiotik Ampisilin-Sulbaktam dengan dosis $3 \times 1,5 \mathrm{~g}$, sementara dosis yang dianjurkan guideline adalah $3 \mathrm{~g}$ tiap pemberian. Kasus No. 21 terjadi pada pasien yang diberikan antibiotik Sefuroksim dengan dosis $1 \mathrm{~g}$ tiap pemberian. Hal ini tidak sesuai dengan guideline bahwa dosis Sefuroksim adalah $750 \mathrm{mg}$ tiap pemberian (APhA, 2015; IDSA, 2019; IDSA, 2016; Jhon Hopkins, 2016; PDPI, 2014; PDPI, 2005).

\section{Kategori II B (penggunaan antibiotik tidak tepat interval pemberian)}

Penggunaan antibiotik yang tidak tepat interval pemberian yaitu pemakaian antibiotik dengan interval yang tidak konstan. Hal ini dapat menyebabkan kadar obat dalam darah tidak 
teratur, sehingga tidak didapatkan kadar obat yang steady state yang diperlukan antibiotik untuk membunuh mikroorganisme. Interval pemberian yang lebih pendek dari yang direkomendasikan dapat menyebabkan peningkatan kadar obat dalam tubuh yang bisa menimbulkan toksisitas obat. Interval pemberian antibiotik yang lebih panjang dari yang direkomendasikan dapat menyebabkan penurunan kadar obat dalam tubuh atau kadar obat di bawah konsentrasi minimal yang dapat menimbulkan efek terapi, sehingga mikroorganisme mudah resisten karena kadar obat tidak cukup untuk membunuh mikroorganisme tersebut.

Analisis ketidaktepatan interval pemberian dilakukan dengan membandingkan interval pemberian antibiotik yang tertulis di rekam medis dengan guideline APhA (2015), IDSA (2019), PDPI (2014), dan Jhon Hopkins Antibiotic Guideline (2016). Berdasarkan hasil evaluasi didapatkan 14 kasus yang penggunaannya tidak tepat interval (kategori II B) yaitu kasus penggunaan antibiotik Ampisilin-Sulbaktam (kasus No. 1, 3, 4, 8, 9, 11, 13, 14, dan 17), kasus penggunaan kombinasi antibiotik Levofloksasin degan Seftriakson (kasus No. 16) dan kasus penggunaan antibiotik Seftriakson (kasus No. 18, 26, 34, dan 39).

\section{Kategori II C (penggunaan antibiotik tidak tepat rute)}

Penggunaan antibiotik tidak tepat rute artinya jalur pemberian antibiotik yang digunakan tidak sesuai dengan jalur pemberian yang direkomendasikan oleh guideline yang digunakan. Analisis ketepatan rute pemberian, yaitu dilakukan perbandingan rute pemberian yang tertulis di rekam medis dengan rute pemberian yang ada di guideline. Rute pemberian antibiotik untuk pasien pneumonia rawat inap adalah rute parenteral melalui injeksi intravena (APhA, 2015; IDSA, 2019; IDSA, 2016; PDPI, 2014; Jhon Hopkins Antibiotic Guideline, 2016). Berdasarkan hasil evaluasi, semua kasus pengggunaan antibiotik lolos penilaian Gyssens dan tidak ada yang masuk kategori II C. Hal ini karena semua kasus penggunaan antibiotik diberikan secara parenteral melalui injeksi intravena.

\section{Kategori I (penggunaan antibiotik tidak tepat waktu)}

Penggunaan antibiotik tidak tepat waktu artinya pemberian antibiotik tidak sesuai dengan waktu pemberian obat. Ketepatan waktu pemberian obat pada penelitian ini dievaluasi dengan membandingkan antara waktu pemberian antibiotik pada Lembar Pemberian Obat yang ada di rekam medis dan interval penggunaan antibiotik tersebut. Berdasarkan hasil evaluasi didapatkan 7 kasus yang tidak lolos penilaian Gyssens dan masuk kategori I yaitu kasus penggunaan antibiotik Ampisilin-Sulbaktam (kasus No. 1), Levofloksasin (kasus No. 7), Seftriakson (kasus No. 18) dan Sefoperazon (kasus No. 19, 30, 37).

\section{Kategori 0 (penggunaan antibiotik rasional)}

Penggunaan antibiotik rasional yaitu penggunaan antibiotik yang sesuai dengan kebutuhan klinis pasien, antibiotik yang biayanya murah dan berkualitas, antibiotik spektrum sempit, antibiotik yang toksisitasnya rendah, Indikasi penggunaan antibiotik adekuat, dosis yang adekuat, tepat interval pemberian, tepat lama pemberian, tepat rute pemberian dan tepat waktu pemberian (Gyssens, 2005). Berdasarkan hasil evaluasi, didapatkan sebanyak 9 kasus yang termasuk kategori 0, yaitu antibiotik Levofloksasin (kasus No. 2, 15, 27, 31, 33, 35, dan 42) dan kombinasi Levofloksasin+Sefoperazon (kasus No. 6 dan 10).

Berdasarkan Tabel 3 diketahui bahwa penggunaan antibiotik rasional (kategori 0) pada pasien pneumonia adalah sebanyak 9 kasus $(13,24 \%)$. Hasil penggunaan antibiotik yang rasional pada penelitian ini lebih bagus daripada penelitian selaras yang di lakukan oleh Dewi dan Mutmainah (2014) di salah satu balai kesehatan di Kota Surakarta dengan persentase antibiotik 
yang masuk kategori 0 sebesar $11,11 \%$. Namun, hasil penggunaan antibiotik rasional pada pasien pneumonia di salah satu rumah sakit Kota Semarang lebih bagus daripada hasil evaluasi penggunaan antibiotik rasional di RSUD Kanjuruhan dengan persentase antibiotik yang masuk kategori 0 sebesar 32,3\% (Pangestika dkk., 2018).

Hasil evaluasi metode Gyssens menunjukkan penggunaan antibiotik yang tidak rasional (kategori I-IV) sebanyak $86,76 \%$ yang terdiri atas $38,24 \%$ kategori IV A (ada antibiotik yang lebih efektif), 2,94\% kategori IV B (ada antibiotik lain yang lebih tidak toksik/aman), 11,76\% kategori IV C (ada antibiotik lain yang lebih murah), 2,94\% kategori II A (penggunaan antibiotik tidak tepat dosis), 20,59\% kategori II B (penggunaan antibiotik tidak tepat interval pemberian), dan 10,29\% kategori I (penggunaan antibiotik tidak tepat waktu). Dampak penggunaan antibiotik yang tidak rasional pada penelitian ini menyebabkan pasien mendapatkan terapi yang kurang efektif, terapi yang kurang aman, biaya pengobatan yang mahal, dan rejimen dosis terapi yang tidak adekuat. Penelitian ini memiliki keterbatasan yaitu peneliti tidak dapat melakukan intervensi, konfirmasi, dan rekomendasi ke dokter terkait penggunaan antibiotik yang sesuai dengan penilaian Gyssens. Penelitian lebih lanjut secara prospektif perlu dilakukan agar peneliti bisa berdiskusi dengan dokter terkait alasan penggunaan antibiotik tersebut.

\section{SIMPULAN}

Berdasarkan hasil evaluasi kualitatif penggunaan antibiotik pada pasien pneumonia rawat inap RS " $X$ " di Malang dapat disimpulkan bahwa kualitas penggunaan antibiotik pada pasien pneumonia dengan metode Gyssens termasuk tidak rasional. Hal ini dibuktikan dengan tingginya persentase penilaian Gyssens kategori IV, IIA, IIB, dan I. Kualitas penggunaan antibiotik pada pasien pneumonia rawat inap perlu ditingkatkan agar pasien terhindar dari kejadian resistensi antibiotik.

\section{PENDANAAN DAN ETIK}

Penelitian ini didanai oleh LP2M UIN Maulana Malik Ibrahim Malang dengan nomor DIPA BLU-DIPA 025.04.2.423812/2019. Penelitian ini telah mendapatkan persetujuan laik etik dari komisi etik RSUD Kanjuruhan dengan nomor kelaikan etik 72.1/EA.KEPK-019/35.07.208/2019.

\section{PUSTAKA ACUAN}

Andayani, N 2014, 'Tingkat Mortalitas Dan Prognosis Pasien Pneumonia Komunitas Dengan Sistem Skoring Curb-65 Di Ruang Rawat Inap Paru RSUD Dr. Zainoel Abidin Banda Aceh', Jurnal Kedokteran Syiah Kuala, Vol. 14, No. 1, 14-19.

[APhA] American Pharmacist Association 2015, Drug Information Handbook 24 Edition. Lexicomp, Amerika Serikat.

Aulia, R \& Indriastuti, C 2017, 'Evaluasi Penggunaan Antibiotik Pada Pasien Pneumonia Di Rumah Sakit PKU Muhammadiyah Bantul', Naskah Publikasi.

Dewi, NT \& Nurul, M 2014, Kajian Penggunaan Antibiotik Pada Pasien Pneumonia Dengan Metode Gyssens Di Balai Kesehatan " $X$ " Surakarta Tahun 2012-2013, [SKRIPSI], Universitas Muhammadiyah Surakarta, Surakarta.

Dipiro, JT, Wells, BG, Schwinghammer, TL \& Dipiro, CV 2015, Pharmacotherapy Handbook, Ninth Edition, McGraw-Hill Education Companies, Inggris.

[Ditjen P2PL] Direktorat Jenderal Pengendalian Penyakit dan Penyehatan Lingkungan Kemenkes RI 2015, Peringatan Hari Pneumonia Sedunia 2015: Kesetaraan Akses terhadap Pencegahan dan Penatalaksanaan Pneumonia, Kemenkes RI, Jakarta. 
Dorland, WN 2014, Kamus Saku Kedokteran Dorland Ed. 29. Terjemahan oleh Hartanto, YB, Nirmala, $\quad$ WK, Ardy \& Setiono, Elsevier, Jakarta.

[LKPP] Lembaga Kebijakan Pengadaan Barang/Jasa Pemerintah 2018, e-catalog obat 2018, https://e-katalog.lkpp.go.id/ , diakses tanggal 18 Desember 2019.

Elfidasari, D, Noriko, N, Mirasaraswati, A, Feroza, A \& Canadianti SF 2013, 'Deteksi Bakteri Klebsiella pneumonia pada Beberapa jenis Rokok Konsumsi Masyarakat', Jurnal Al-Azhar Indonesia Seri Sains Dan Teknologi, Vol. 2, No. 1, 41-47.

Elvina, R, Rahmi, N, dan Sandra AO 2017, 'Evaluasi Penggunaan Antibiotik pada Pasien Community Acquired Pneumonia (CAP) di Instalasi Rawat Inap Rumah Sakit " $X$ " Jakarta', Jurnal Pharmacy, Vol. 14, No. 1, 64-67.

Fair, JF and Yitzhak T 2014, 'Antibiotics and Bacterial Resistance in the 21st Century', Journal Perspectives in Medical Chemistry, Vol.6, 25-64.

Farida, Y, Putri, VW, Hanafi, M, dan Nurmayda SH 2020, 'Profil Pasien dan Penggunaan Antibiotik pada Kasus Community-Acquired Pneumonia Rawat Inap di Rumah Sakit Akademik Wilayah Sukoharjo', Journal of Pharmaceutical Science and Clinical Research, Vol. 5, No. 2, 151-164.

Gyssens, IC 2005, Audit for Monitoring the Quality of Antimicrobial Prescription. Dalam: Gould, IVM, penyunting, Antibiotic Policies: Theory and practice, Kluwer Academic Publishers, New York.

Hasan, H \& Rena AM 2017, 'Perubahan Fungsi Paru Pada Usia Tua', Jurnal Respirasi, Vol. 3, No.2, 52-57.

[IDSA] Infectious Disease Society of America 2016, 'Management of Adults With Hospital-acquired and Ventilator-associated Pneumonia: 2016 Clinical Practice Guidelines', Clinical Infectious Diseases, Vol. 63, No. 5, e61-e111.

[IDSA] Infectious Disease Society of America 2019, 'Diagnosis and Treatment of Adults with Community-Acquired Pneumonia. An Official Clinical Practice Guideline of the American

Thoracic Society and Infectious Diseases Society of America'. American Journal of Respiratory and Critical Care Medicine, Volume 200, Nomor 7: e45-e67.

Jalil, ANA 2015, Profil Pasien Pneumonia Komunitas di Rumah Sakit Umum Cengkareng tahun 2013-

2014, [Skripsi], FKIK UIN Syarif Hidayatullah, Jakarta.

[Jhon Hopkins] 2016, Antibiotic Guideline 2015-2016, Jhon Hopkins University, Amerika Serikat.

[Kemenkes RI] Kementrian Kesehatan Republik Indonesia 2009, Klasifikasi Umur Menurut

Kategori, Ditjen Yankes, Jakarta.

[Kemenkes RI] Kementrian Kesehatan Republik Indonesia 2011, Pedoman Pelayanan Kefarmasian Untuk Terapi Antibiotik, Depkes RI, Jakarta.

[Kemenkes RI] Kementrian Kesehatan Republik Indonesia 2013a, Pedoman Umum Penggunaan Antibiotik, Kemenkes RI, Jakarta

[Kemenkes RI] Kementrian Kesehatan Republik Indonesia 2013b, Riset Kesehatan Dasar, Balitbang Kemenkes RI, Jakarta.

[Kemenkes RI] Kementrian Kesehatan Republik Indonesia 2018, Riset Kesehatan Dasar, Balitbang Kemenkes RI, Jakarta.

Kurniawan, J, Erly, Rima S 2015, 'Pola Kepekaan Bakteri Penyebab Pneumonia terhadap Antibiotika di Laboratorium Mikrobiologi RSUP Dr. M. Djamil Padang Periode Januari sampai Desember 2011', Jurnal Kesehatan Andalas, Vol. 4, No. 2, 562-566.

Lanks, CW, Musani, Al, and David WH 2019, Community-Acquired Pneumonia and Hospital Acquired Pneumonia. Elsevier Vol. 103, No.3, 487-501. 
Marsono, Y 2015, Evaluasi Penggunaan Antibiotik Pada Pasien Pneumonia Dengan Metode Gyssens Di Instalasi Rawat Inap Rumah Sakit Umum Daerah Dokter Moewardi Surakarta Tahun 2013, [Skripsi], Universitas Muhammadiyah Surakarta, Surakarta.

[MIMS] Monthly Index of Medical Specialities 2018, MIMS Indonesia Petunjuk Konsultasi Ed.18, Bhuana Ilmu Populer, Jakarta.

Muhammad, OR 2018, Evaluasi Penggunaan Antibiotik Dengan Metode ATC/DDD Pada Pasien pneumonia di Instalasi Rawat Inap RSUD Dr. Moewardi tahun 2017, [SKRIPSI], Universitas Muhammadiyah Surakarta, Surakarta.

Pangestika, ND, Rahayu \& Masfiyah 2018, 'Hubungan Kualitas Penggunaan Antibiotik Terhadap Lama Rawat Inap Pasien Pneumonia Periode 2015-2017', Naskah Publikasi.

[PDPI] Perhimpunan Dokter Paru Indonesia 2005, Pneumonia Nosokomial Pedoman Diagnosis \& Penatalaksanaan di Indosnesia, Perhimpuan Dokter Paru Indonesia, Jakarta.

[PDPI] Perhimpunan Dokter Paru Indonesia 2014, Pedoman Diagnosis dan Penatalaksanaan Pneumonia Komuniti di Indonesia, Perhimpunan Dokter Paru Indonesia, Jakarta.

[Permenkes RI] Peraturan Menteri Kesehatan Republik Indonesia Nomor 8 2015, Program Pengendalian Resistensi Antimikroba di Rumah Sakit, Kemenkes RI, Jakarta.

Peto, L, Nadjm, B, Horby, P et al 2014, The Bacterial Aetiology of Adult Community-Acquired Pneumonia in Asia: A Systematic Review', PUBMED, Vol.108, No. 6, 326-337.

Prina, E, Ranzani, OT, and Torres A 2015. Community-Acquired Pneumonia. Lancet, Vol. 386, 1097 1108.

Ramirez, JA, Wiemken, TL, Peyrani, P et al 2017, 'Adults Hospitalized With Pneumonia in the United

States: Incidence, Epidemiology, and Mortality', Cliniclal infectious disease, Vol. 65, No. 11, 1806-

1812.

Rusmini, H 2015, 'Gambaran Penggunaan Antibiotik pada Pasien Pneumonia dengan Menggunakan Metode Gyssens di Rawat Inap Rumah Sakit Umum Daerah (RSUD) H. Abdul Moeloek Tahun 2015', Jurnal Medika Malahayati, Vol. 3, No. 2, 61-64.

Safitri, SA 2017, Evaluasi Penggunaan Antibiotik Pada Pasien Pneumonia Di Instalasi Rawat Inap RS "X" Klaten Tahun 2015, [Skripsi], Universitas Muhammadiyah Surakarta, Surakarta.

Torres, A,Peetermans, WE \& Viegi G et al., 2013, 'Risk factors for community-acquired pneumonia in adults in Europe: a literature review', Thorax, No. 68,1057-1065.

[WHO] World Health Organization, 2014, World Pneumonia Day 2014,Pneumonia Fact Sheet, November 12 th edition, diakses pada tanggal 8 Mei 2019, dari sumber: http://worldpneumoniaday.org/wpcontent/uploads/2014/11/FinalWPD2014FactSheet1.pdf. 